\title{
Long-term Complete Remission in a 71-year-old Patient with AML-M7 after Low-dose Cytarabine Induction and Intermediate-dose Cytarabine Consolidation Treatment
}

\author{
Ji Hyun Kwon, M.D. ${ }^{1}$, Ji Won Kim, M.D. ${ }^{1}$, Jin Hyun Park, M.D. ${ }^{1}$, \\ Youngil Koh, M.D. ${ }^{1}$, Jee Hyun Kim, M.D. ${ }^{1}$, Su Mi Bang, M.D. ${ }^{1}$, \\ Junghan Song, M.D. ${ }^{2}$ and Jong-Seok Lee, M.D. ${ }^{1}$ \\ Departments of ${ }^{1}$ Internal Medicine, ${ }^{2}$ Laboratory Medicine, Seoul National University College of Medicine, Seoul, Korea
}

\begin{abstract}
The authors describe the case of a 71-year-old patient with acute megakaryocytic leukemia (AML-M7) who was successfully treated with low-dose cytarabine induction followed by intermediate-dose cytarabine consolidation therapy. The patient presented with infection and rapidly increasing blood blasts. The diagnosis was consistent with AML-M7 with a normal karyotype. Peripheral blood blasts decreased rapidly upon low-dose cytarabine administration, and the patient achieved complete remission after two courses of low-dose cytarabine $\left(10 \mathrm{mg} / \mathrm{m}^{2}\right.$ bid for 12 days). Consolidation therapy with intermediate-dose cytarabine $\left(1.0 \mathrm{~g} / \mathrm{m}^{2}\right.$ bid on day 1,3 and 5) was then instituted without serious complication. He remained in complete remission at the time of writing 47 month after diagnosis. In spite of multiple poor prognostic factors, this patient showed excellent treatment outcome through low-dose cytarabine induction and intermediate-dose cytarabine consolidation. It needs to be validated whether acute leukemia with a megakaryocytic morphology is exceptionally sensitive to cytarabine. (Korean J Hematol 2009;44:244-248.)
\end{abstract}

Key Words: Acute myeloid leukemia, Acute megakaryocytic leukemia, Elderly, Low-dose cytosine arabinoside, Intermediate-dose cytosine arabinoside

\section{INTRODUCTION}

Acute myeloid leukemia (AML) is common in the elderly as its incidence increases with age, especially after 60 . Treatment outcomes for older AML patients are poor, and have not improved over the last two decades. Many factors contribute to this poor prognosis, such as, the presence of co-morbidities, poor performance status, and its more aggressive biologic features which include high-risk cytogenetics, multi-drug resistant phenotypes, and secondary leukemia. ${ }^{1)}$

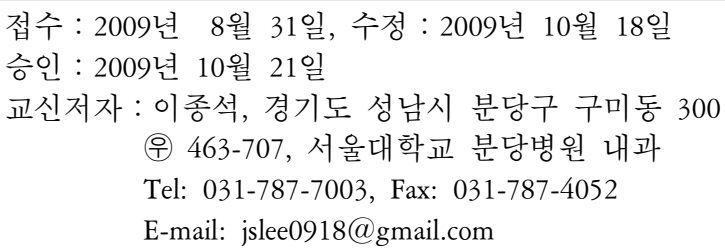

Available indirect data support the use of intensive chemotherapy in older patients, but many of these patients are not fit for intensive chemotherapy because of co-morbidities or a poor performance status, and even those that are fit, only achieve a complete response rate of about $50 \%,{ }^{2-5)}$ with a treatment-related mortality rate of $20 \sim 40 \%,{ }^{6,7)}$ and furthermore, durable remission is rare.

Low-dose cytarabine has been investigated for more than 20 years and has demonstrated survival advantages over best supportive care and over hydroxyurea for the treatment of elderly

\footnotetext{
Correspondence to : Jong-Seok Lee, M.D.

Department of Internal Medicine, Seoul National University Bundang Hospital,

300, Gumi-dong, Bundang-gu, Seongnam 463-707, Korea

Tel: +82-31-787-7003, Fax: +82-31-787-4052

E-mail: jslee0918@gmail.com
} 
patients deemed unfit for intensive chemotherapy.

Acute megakaryoblastic leukemia (AML M7), which is classified by French-American-British (FAB) morphological criteria is a rare subtype of AML, and because of this rarity, insufficient data is available about the course of disease, treatment response, or survival rate. However, its prognosis has been thought to be poorer than those of other subtypes. ${ }^{8,9)}$

Here, we report on the long-term survival of a 71-year-old patient with AML M7 who entered CR on low-dose cytarabine, and who was consolidated with intermediate-dose cytarabine.

\section{CASE REPORT}

A 71-year-old male presented with fever, dyspnea on exertion, and gum bleeding of 2 months duration in September 2005.

His body temperature was $38.4^{\circ} \mathrm{C}$. A physical examination revealed anemic conjunctiva, purpura in the left orbital area, and crackles in both lower chest lobes. There was no hepato-splenomegaly or lymph node enlargement. His peripheral white blood cell count was $28,250 / \mathrm{nL}$ with $12.2 \%$ neutrophils, $22.5 \%$ lymphocytes and $60 \%$ blasts, and his hemoglobin and platelet count were of 6.8 $\mathrm{g} / \mathrm{dL}$ and $15,000 / \mu \mathrm{L}$ respectively. Blood chemistry showed, LDH 1,301 IU/L, uric acid $12.2 \mathrm{mg} / \mathrm{dL}$, BUN $19 \mathrm{mg} / \mathrm{dL}$, and creatinine $1.3 \mathrm{mg} / \mathrm{dL}$.

Chest CT revealed multifocal ground-glass opacities in both lung fields. Empiric antibiotic therapy with piperacillin and tobramycin was initiated under the impression of atypical pneumonia complicating acute leukemia. Later, these were changed to cefotaxim, levofloxacin, and metronidazole following the identification of Bacillus species in two blood cultures. A bone marrow (BM) examination (Fig. 1) revealed hypercellular marrow with $71 \%$ blasts, which were PAS-negative, peroxidase-negative, and ANAEnegative of immunophenotype CD34 (-), CD33 $(+)$, CD13 $(+)$ and CD61 (+). Conventional Gbanding and FISH (fluorescent in situ hybridization) for PML/RARa, AML/ETO, MLL, and inv-16 showed no cytogenetic abnormalities. The diagnosis was consistent with AML-M7 with a normal karyotype.

Medical history taking revealed gouty arthritis and hypertension, and that he had been taking antihypertensives for 10 years.

The patient's condition stabilized after controlling the infection and a transfusion, but he refused further therapy, and was discharged on the $15^{\text {th }}$ hospital day.

However, 3 days later, he was readmitted with

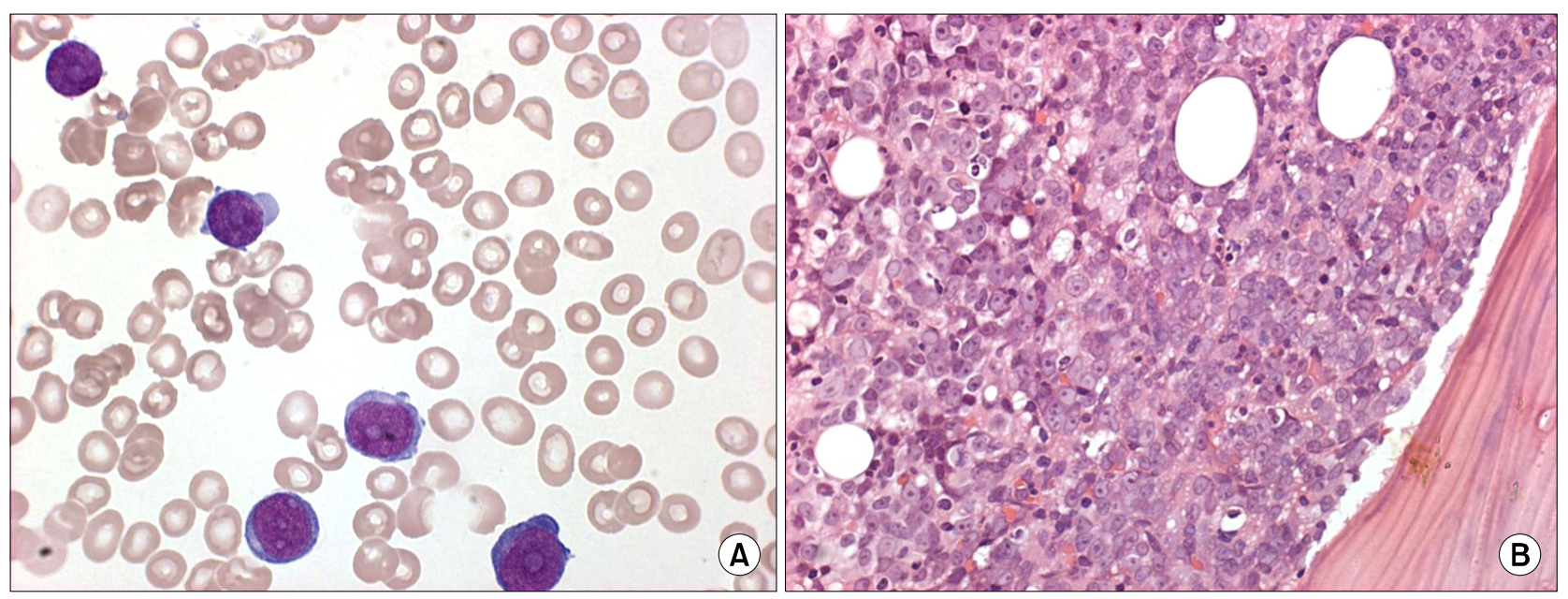

Fig. 1. Bone marrow (BM) aspiration \& biopsy (H\&E). (A) BM aspiration cytology $(\times 1,000)$; blasts with cytoplasmic bleb. (B) BM section ( $\times 400)$; hypercellular, packed with blasts. 
petechiae, severe gum bleeding, pain in the right wrist joint, and fever. At this time, his blood leukocyte count was $38,370 / \mu \mathrm{L}$ with $80 \%$ blasts and a hemoglobin level of $6.9 \mathrm{~g} / \mathrm{dL}$ and a platelet count of $19,000 / \mu \mathrm{L}$. Antibiotics were administered for septic arthritis of the right wrist. On the $13^{\text {th }}$ hospital day, his blood WBC count rose to $66,280 / \mu \mathrm{L}$ with $93 \%$ blasts. Due to the rapidly increasing blast count, we decided on cytoreduction with low-dose cytarabine chemotherapy.

Cytarabine was given subcutaneously at $10 \mathrm{mg} /$ $\mathrm{m}^{2}$ every 12 hours for 12 days. His blood WBC and blast counts fell rapidly to $10,980 / \mu \mathrm{L}(64 \%$ blasts), $3,330 / \mu \mathrm{L}(29 \%$ blasts $)$ and $1,660 / \mu \mathrm{L}$ ( $9 \%$ blasts) on $3^{\text {rd }}, 5^{\text {th }}$, and $7^{\text {th }}$ days, respectively, after starting treatment. At the end of a 12 day course of low-dose cytarabine therapy, blasts in bone marrow were reduced to $25.4 \%$, and $16^{\text {th }}$ days after treatment-initiation (after a 4 day rest period), he was given a second course of low-dose cytarabine chemotherapy. On completion of this second course, his BM blast count decreased to $3.6 \%$. These two courses of low-dose cytarabine treatment were well-tolerated and he was discharged without any serious problem.

At 1-month following completion of the $2^{\text {nd }}$ course of therapy, the patient had a normal blood count (hemoglobin $11.0 \mathrm{~g} / \mathrm{dL}$, leukocytes 6,540/ $\mu \mathrm{L}$ with $56 \%$ neutrophils, $31 \%$ lymphocytes, and $10 \%$ monocytes, and platelet level of $332,000 / \mu$ L). A repeat BM examination revealed $1.9 \%$ blasts among all nucleated cells.

With a diagnosis of complete remission (CR), we decided to initiate consolidation therapy with intermediate-dose cytarabine. Cytarabine was given at $1,000 \mathrm{mg} / \mathrm{m}^{2}$ as $2 \mathrm{hr}$ infusion twice daily on days 1, 3, and 5 (Total 6 doses). He underwent two courses of consolidation therapy without serious complication. Now, 47 months after the first diagnosis of AML-M7, he remains in good health and in hematologic complete remission.

\section{DISCUSSION}

Acute myelogenous leukemia is a disease of older adults, with a median age at onset of over 60 years. Treatment outcomes for older patients with AML are poor, due to refractory nature of the disease and frailty. Although indirect findings support the use of intensive chemotherapy in older patients, most will derive little benefit from this approach. Remission rate may be improved by intensive treatment, but this is not necessarily converted into a survival improvement due to a high treatment-related death rate. Reported survival data probably overestimate the effectiveness of intensive therapy in older patients, due to a tendency to treat only fit older patients. ${ }^{1,10)}$

Low-dose cytarabine has been shown to offer a survival advantage over best supportive care and over hydroxyurea for the treatment for AML in the elderly. ${ }^{11)}$ As compared with intensive chemotherapy, low-dose cytarabine produces similar overall survival and CR duration despite fewer complete remissions. ${ }^{12}$ Furthermore, the early death rate, the incidence of infectious complications during treatment, and hospital-stays were significantly lower for low-dose cytarabine than intensive chemotherapy.

No validated post-remission strategy is available for elderly patients. ${ }^{13)}$ Although high dose cytarabine is the most active and commonly used post-remission therapy in AML, it has been associated with severe neurologic toxicity in approximately one third of elderly patients treated. ${ }^{14)}$ We chose intermediate-dose cytarabine which has been reported to be relatively safe as post-remission therapy for elderly AML patienst. ${ }^{15}$ )

Acute megakaryoblastic leukemia (AML-M7) is a rare form of AML, and has a bimodal age distribution, one peak occurs in adults and the other in children, especially in children with Down's syndrome. Furthermore, the prognosis of AML-M7 in adults has been reported to be poorer than those of other subtypes. ${ }^{8,9)}$ 
Our patient had many unfavorable prognostic factors, such as, an advanced age, the M7 subtype, combined infection, and a poor performance status. However, he responded rapidly to lowdose cytarabine and achieved CR. Subsequently, he was administered two courses of intermediatdose cytarabine as post-remission therapy, and remained in CR for more than 47 months. Our findings suggest that a study be undertaken to determine whether acute leukemia with a megakaryocytic morphology is exceptionally sensitivity to cytarabine.

\section{요 약}

본 증례보고에서는 급성거대핵모세포 백혈병 으로 진단받은 71세 환자에서 저용량 시타라빈 요법으로 관해유도에 성공한 후 중등도 용량 시 타라빈 공고요법으로 장기 생존을 유지한 1 예를 보고하였다. 환자는 폐감염과 말초혈액 내 백혈 구증가증으로 발현하여 정상 핵형의 급성거대핵 모세포백혈병으로 진단받았다. 2회의 저용량 시 타라빈 요법(체표면적당 $10 \mathrm{mg}, 12$ 일)으로 관해 유도에 성공한 환자는 공고요법으로 중등도 용량 시타라빈(체표면적당 1 g. 1, 3, 5일) 요법을 시행 하였으며, 특별한 합병증 없이 47개월간 생존하 였다. 본 증례의 환자는 여러 가지 불량한 예후인 자에도 불구하고 저용량 시타라빈 유도요법 및 중등도 용량 시타라빈 공고요법을 통해 좋은 결 과를 보였다. 향후 성인에서 급성거대핵모세포백 혈병의 항암제 감수성에 대해 추가 연구가 필요 할 것으로 생각된다.

\section{REFERENCES}

1) Kuendgen A, Germing U. Emerging treatment strategies for acute myeloid leukemia (AML) in the elderly. Cancer Treat Rev 2009;35:97-120.

2) Vey N, Coso D, Bardou VJ, et al. The benefit of induction chemotherapy in patients age $>$ or $=75$ years. Cancer 2004;101:325-31.

3) Reiffers J, Huguet F, Stoppa AM, Michallet M, Hurteloup P. Intensive induction chemotherapy in elderly patients. The BGMT Group. Br J Haematol 1992;82:175-6.

4) Löwenberg B, Suciu S, Archimbaud E, et al. Mito- xantrone versus daunorubicin in induction-consolidation chemotherapy--the value of low-dose cytarabine for maintenance of remission, and an assessment of prognostic factors in acute myeloid leukemia in the elderly: final report. European organization for the research and treatment of cancer and the dutchbelgian hemato-oncology cooperative hovon group. J Clin Oncol 1998;16:872-81.

5) Baudard M, Marie JP, Cadiou M, Viguié F, Zittoun R. Acute myelogenous leukaemia in the elderly: retrospective study of 235 consecutive patients. $\mathrm{Br} \mathrm{J}$ Haematol 1994;86:82-91.

6) Appelbaum FR, Gundacker H, Head DR, et al. Age and acute myeloid leukemia. Blood 2006;107:34815.

7) Kantarjian H, O'Brien S, Cortes J, et al. Results of intensive chemotherapy in 998 patients age 65 years or older with acute myeloid leukemia or high-risk myelodysplastic syndrome: predictive prognostic models for outcome. Cancer 2006;106:1090-8.

8) Pagano L, Pulsoni A, Vignetti M, et al. Acute megakaryoblastic leukemia: experience of GIMEMA trials. Leukemia 2002;16:1622-6.

9) Tallman MS, Neuberg D, Bennett JM, et al. Acute megakaryocytic leukemia: the eastern cooperative oncology group experience. Blood 2000;96:240511.

10) Deschler B, de Witte T, Mertelsmann R, Lübbert M. Treatment decision-making for older patients with high-risk myelodysplastic syndrome or acute myeloid leukemia: problems and approaches. Haematologica 2006;91:1513-22.

11) Burnett AK, Milligan D, Prentice AG, et al. A comparison of low-dose cytarabine and hydroxyurea with or without all-trans retinoic acid for acute myeloid leukemia and high-risk myelodysplastic syndrome in patients not considered fit for intensive treatment. Cancer 2007;109:1114-24.

12) Tilly H, Castaigne S, Bordessoule D, et al. Low-dose cytarabine versus intensive chemotherapy in the treatment of acute nonlymphocytic leukemia in the elderly. J Clin Oncol 1990;8:272-9.

13) Goldstone AH, Burnett AK, Wheatley K, Smith AG, Hutchinson RM, Clark RE. Attempts to improve treatment outcomes in acute myeloid leukemia (AML) in older patients: the results of the United Kingdom Medical Research Council AML11 trial. Blood 2001;98:1302-11.

14) Mayer RJ, Davis RB, Schiffer CA, et al. Intensive postremission chemotherapy in adults with acute 
myeloid leukemia. Cancer and Leukemia Group B. N Engl J Med 1994;331:896-903.

15) Sperr WR, Piribauer M, Wimazal F, et al. A novel effective and safe consolidation for patients over 60 years with acute myeloid leukemia: intermediate dose cytarabine $\left(2 \times 1 \mathrm{~g} / \mathrm{m}^{2}\right.$ on days 1,3 , and 5$)$. Clin Cancer Res 2004;10:3965-71. 